\title{
PENGARUH PEMBERIAN TERAPI BERMAIN TERHADAP PEMBELAJARAN MITIGASI BENCANA PADA ANAK AUTIS BERBASIS DISASTER NURSING COMPETENCY
}

\section{THE INFLUENCE OF PLAY THERAPY ON LEARNING OF DISASTER MITIGATION FOR CHILDREN WITH AUTISM BASED ON DISASTER NURSING COMPETENCY}

\author{
Fika Nur Indriasari ${ }^{1}$, Linda Widyarani ${ }^{2 *}$, Prima Daniyati Kusuma ${ }^{3}$
}

\author{
${ }^{1}$ Akademi Keperawatan Notokusumo Yogyakarta, Jl. Bener No. 26 Tegalrejo Yogyakarta, \\ email: fheekha.nur@gmail.com , Indonesia \\ ${ }^{*}{ }^{2}$ Akademi Keperawatan Notokusumo Yogyakarta, Jl. Bener No. 26 Tegalrejo Yogyakarta, \\ email: lindawidyarani@gmail.com, Indonesia \\ ${ }^{3}$ Akademi Keperawatan Notokusumo Yogyakarta, Jl. Bener No. 26 Tegalrejo Yogyakarta, \\ email: primadaniyati@gmail.com, Indonesia
}

\begin{abstract}
Background: A powerful earthquake in Yogyakarta, causing major damage and many deaths. Children with autism are more vulnerable and have a greater risk of earthquake because they are have an intellectual, social and verbal disability to safe life independently.

Objective: This research discussed the influence of play therapy on learning of disaster mitigation for children with autism.

Method: This research used qualitative descriptive design and consider a sample of 30 children with autism in SLB N Pembina Yogyakarta. Play therapy in this research use drawing and coloring methods, also watching video about disaster preparedness.

Results: Play therapy could effectively be applied as earthquake mitigation lesson to children with autism in SLB N Pembina Yogyakarta. Before interventions, there were 2 children (7\%) able to draw on actions when an earthquake occurred, and increased to 19 children $(63,33 \%)$ after interventions.

Conclusion: Play therapy could be effectively applied to children with autism as earthquake disaster mitigation showed by an increase of children's drawing and coloring ability on actions when an earthquake occurred for as much as $56,33 \%$.
\end{abstract}

Keyword: Children with autism, mitigation ability, play therapy

\section{PENDAHULUAN}

Peristiwa gempa bumi banyak terjadi di wilayah Indonesia. Bencana alam gempa bumi tersebut antara lain terjadi beberapa kali di wilayah Aceh, Nias, Padang, Jawa Tengah, Daerah Istimewa Yogyakarta, Nusa Tenggara Barat, dan Nusa Tenggara Timur. Berdasarkan letak geografis, wilayah kepulauan Indonesia terletak di tempat pertemuan tiga lempeng besar dunia, yaitu lempeng India-Australia (bagian selatan), lempeng Eurasia (bagian barat dan utara) dan lempeng Pasifik (bagian timur). Oleh karena itu maka wilayah Indonesia merupakan wilayah yang paling sering terjadi gempa bumi. ${ }^{1}$ Propinsi Daerah Istimewa Yogyakarta (DIY) merupakan wilayah yang rawan terhadap terjadinya gempa bumi, dikarenakan DIY berada di dekat pertemuan dua lempeng dunia dan juga berada di atas jalur gunung berapi yang aktif di dunia. Posisi ini menjadikan DIY rentan terhadap terjadinya bencana alam gempa bumi tektonik dan gempa bumi vulkanik. ${ }^{2}$

Kewaspadaan sangatlah penting mengingat bahwa jumlah korban jiwa dan 
kehilangan materi yang tidak sedikit di setiap kejadian bencana, seperti yang terjadi di Yogyakarta pada tanggal 27 Mei 2006. Berdasarkan informasi data dari BNPB (2014) jumlah korban mencapai 5.716 orang tewas dan 37.927 orang luka-luka. Gempa bumi tersebut membuat banyak orang terperangkap di dalam rumah khususnya anak-anak dan orang tua karena terjadi di pagi hari sehingga mayoritas korban merupakan orang yang berusia lanjut dan anak-anak yang kemungkinan tidak sempat menyelamatkan diri ketika gempa berlangsung. Hal ini memperlihatkan masih lemahnya kesiapan menghadapi bencana di Indonesia. $^{3}$

Kesiapsiagaan menghadapi bencana didefinisikan sebagai tindakan untuk meningkatkan keselamatan hidup saat terjadi bencana. Kesiapsiagaan juga mencakup tindakan yang dirancang untuk meningkatkan kemampuan guna melindungi property dari kerusakan dan kekacauan akibat bencana serta kemampuan untuk terlibat dalam kegiatan restorasi dan pemulihan awal pasca bencana. ${ }^{4}$ Beberapa faktor penyebab utama timbulnya banyak korban akibat bencana gempa adalah karena kurangnya pengetahuan masyarakat tentang bencana dan kurangnya kesiapan masyarakat dalam mengantisipasi bencana tersebut. Khusus untuk gempa bumi korban yang meninggal banyak terjadi karena tertimpa reruntuhan akibat bangunan yang roboh. Di antara korban jiwa tersebut, paling banyak adalah wanita dan anak-anak. ${ }^{5}$

Sekolah yang lebih aman diperlukan untuk melindungi hidup anak-anak selama terjadinya bencana. Konsep keselamatan sekolah tidak dibatasi hanya untuk mencegah runtuhnya gedung sekolah saat bencana dan keselamatan guru dan siswa, tetapi lebih luas lagi untuk mencapai tujuan yang lebih besar, yaitu "manajemen risiko bencana", karena anak-anak berperan sebagai generasi penerus di masa depan. Apa yang mereka pelajari tentang keselamatan saat ini akan bermanfaat dalam mengembangkan "masyarakat yang tanggap terhadap risiko bencana" dalam jangka panjang. Di sinilah pentingnya pendidikan tentang bencana dalam keselamatan sekolah. ${ }^{6}$

Kelurahan Giwangan terletak di selatan kota Yogyakarta yang berbatasan dengan kota Bantul yang rawan terhadap gempa bumi. Menurut peta kerusakan gempa tahun 2006 yang lalu, daerah Giwangan masuk dalam zona moderate damage area. Jumlah SLB (Sekolah Luar Biasa) di Kelurahan Giwangan Kecamatan Umbulharjo ada satu dengan jumlah siswa autis sebanyak 30 orang. Anak Berkebutuhan Khusus (ABK) merupakan salah satu kelompok paling rentan ketika terjadi bencana. Beberapa dari mereka memiliki hambatan mobilitas untuk melakukan perlindungan bahkan penyelamatan diri secara mandiri sehingga diperlukan adanya informasi bagaimana prosedur atau rencana 
penyelamatan bagi $\mathrm{ABK}$ yang memerlukan bantuan orang di sekitar mereka (misal: guru, teman, staf sekolah). Berdasar dari latar belakang tersebut, maka rumusan masalahnya adalah bagaimana pengaruh metode terapi bermain terhadap kemampuan mitigasi anak-anak berkebutuhan khusus dengan autis dalam menghadapi bencana gempa bumi di Yogyakarta.

\section{BAHAN DAN CARA PENELITIAN}

Jenis penelitian yang digunakan pada penelitian ini adalah deskriptif kualitatif. Penelitian ini dilakukan pada bulan April-Juni 2018. Lokasi penelitian ini adalah di SLB N Pembina Yogyakarta. SLB N Pembina merupakan satu-satunya SLB di kelurahan Giwangan yang mempunyai siswa dari usia sekolah dasar sampai sekolah menengah umum. Cara pengambilan sampel dilakukan dengan melihat data siswa di SLB $N$ Pembina Yogyakarta dengan kriteria inklusi sebagai berikut: anak autis, tidak sedang mengalami sakit, dan bersedia menjadi responden.

Terapi bermain yang digunakan pada penelitian ini adalah menggambar, mendongeng, dan menonton film siaga bencana. Instrumen yang digunakan pada penelitian ini adalah media berupa film kartun siaga bencana gempa bumi, dengan durasi \pm 20 menit dan terbagi menjadi lima scene yang menunjukkan tindakan tepat dan tidak tepat ketika menghadapi bencana gempa bumi. Selain itu, pada penelitian ini juga menggunakan media gambar, seperti buku gambar, pensil warna, spidol, dan crayon.

Pada tahap awal, akan dilakukan pretest yaitu siswa $A B K$ autis diminta menggambarkan bagaimana jika terjadi gempa bumi dan apa yang harus dilakukan. Pretest ini bertujuan untuk mengetahui bagaimana kemampuan awal mitigasi bencana siswa $A B K$ autis saat terjadi bencana gempa bumi. Selanjutnya, siswa ABK tersebut akan diajak bercerita oleh guru SLB tentang kejadian bencana gempa bumi dan dipertontonkan film kartun siaga bencana gempa bumi. Pada tahap akhir, siswa ABK tersebut diminta kembali untuk menggambarkan bagaimana jika terjadi gempa bumi dan apa yang harus dilakukan. Tahap akhir ini untuk mengetahui bagaimana kemampuan mitigasi bencana siswa $A B K$ setelah diberikan intervensi terapi bermain. Selanjutnya, tahap observasi dengan checklist. Observasi dengan melihat hasil gambar dari anak-anak tentang bagaimana jika terjadi gempa serta tindakan yang dilakukan, antusiasme dan keterlibatan anakanak dalam melakukan terapi bermain. Checklist ini untuk menilai kemampuan anak untuk melakukan mitigasi bencana gempa bumi.

\section{HASIL DAN PEMBAHASAN}

Autisme merupakan suatu kumpulan gejala (sindrom) yang diakibatkan oleh kerusakan saraf. Gejalanya sudah tampak sebelum anak mencapai usia tiga tahun. 
Penyandang autisme menunjukkan gangguan komunikasi yang menyimpang. Gangguan komunikasi tersebut dapat terlihat dalam bentuk keterlambatan bicara, tidak bicara, bicara dengan bahasa yang tidak dapat dimengerti (bahasa planet), atau bicara hanya dengan meniru saja (ekolalia). Selain gangguan komunikasi, anak juga menunjukkan gangguan interaksi dengan orang di sekitarnya, baik orang dewasa maupun orang sebayanya. ${ }^{7}$

Pada penelitian ini, jumlah keseluruhan responden adalah 30 anak. Klasifikasi ABK dengan autis di SLB N Pembina ada 3 karakteristik yaitu IQ tinggi, $I Q$ sedang, dan IQ rendah. Sebagian besar berjenis kelamin laki-laki dan termasuk dalam kategori IQ rendah sebanyak 43,3\%. Anak laki-laki cenderung lebih rentan mengalami gangguan perkembangan sistem saraf termasuk autis dibandingkan anak perempuan. Anak laki-laki empat kali lebih rentan terhadap autis dibanding anak perempuan. Penyebab kerentanan terhadap gangguan perkembangan sistem saraf pada anak laki-laki dan perempuan ada pada gen. ${ }^{8}$

Tabel 1. Distribusi Frekuensi Anak Autis di SLB N Pembina Yogyakarta Tahun $2018(n=30)$

\begin{tabular}{|c|c|c|c|c|c|c|c|c|}
\hline \multirow[t]{2}{*}{ Kategori } & \multicolumn{2}{|c|}{$\begin{array}{c}\text { IQ } \\
\text { Tinggi }\end{array}$} & \multicolumn{2}{|c|}{$\begin{array}{c}\text { IQ } \\
\text { Sedang }\end{array}$} & \multicolumn{2}{|c|}{$\begin{array}{c}\text { IQ } \\
\text { Rendah }\end{array}$} & \multicolumn{2}{|c|}{ Jumlah } \\
\hline & $\mathbf{n}$ & $\%$ & $\mathbf{n}$ & $\%$ & $\mathbf{n}$ & $\%$ & $\mathbf{N}$ & $\%$ \\
\hline \multicolumn{9}{|c|}{ Jenis Kelamin } \\
\hline - Laki-laki & 4 & 13,3 & 6 & 20 & 13 & 43,3 & 23 & \multirow[t]{2}{*}{100} \\
\hline - Perempuan & 6 & 20 & 0 & 0 & 1 & 3,3 & 7 & \\
\hline \multicolumn{9}{|c|}{ Tingkat Pendidikan } \\
\hline$-S D$ & 3 & & 3 & & 5 & & 11 & \multirow[t]{3}{*}{100} \\
\hline - SMP & 4 & & 3 & & 4 & & 11 & \\
\hline - SMA & 5 & & 2 & & 1 & & 8 & \\
\hline
\end{tabular}

Sumber : Data Primer, 2018

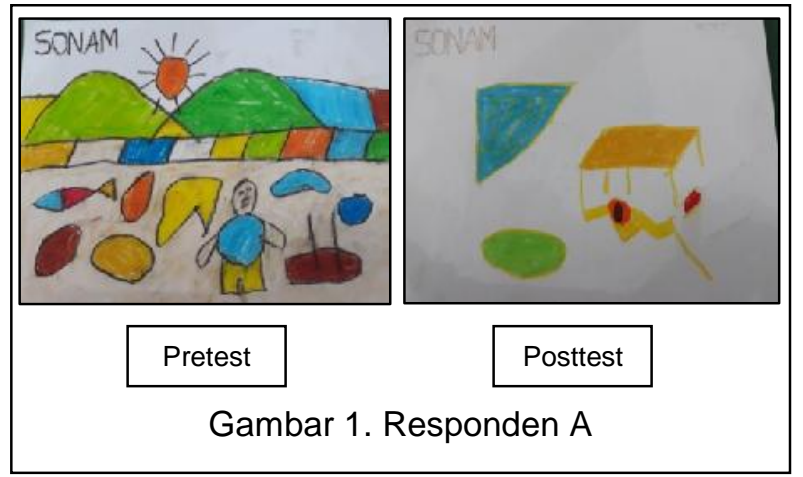

Gambar 1. menunjukkan hasil pretest dan posttest responden A. Pada saat pretest, mereka dibebaskan berekspresi dalam menggambar, para guru atau pengajar memberikan pertanyaan tentang apa yang dilakukan bilamana gempa bumi terjadi, namun pada pretest responden $\mathrm{A}$ keluar dari konsep dan memilih apa yang mereka sukai untuk digambar dalam pikirannya. Pada hasil pretest hanya terlihat gambar pemandangan gunung, matahari, orang, ikan, dan beberapa gambar yang tidak dapat dideskripsikan, sedangkan hasil posttest menunjukkan bahwa gambar orang sedang bersimpuh dan berlindung di bawah meja. Hal ini menunjukkan bahwa responden telah mengetahui bahwa apabila terjadi gempa bumi, tindakan yang dilakukan adalah bersimpuh dan berlindung di bawah meja. Berdasarkan perbandingan gambar pretest dan posttest, terlihat terjadi peningkatan pengetahuan responden.

Menggambar dan mewarnai merupakan salah satu terapi okupasi bagi anak autis. Terapi okupasi merupakan suatu bentuk psikoterapi suportif berupa aktivitasaktivitas yang membangkitkan kemandirian secara manual, kreatif, dan edukasional 
untuk penyesuaian diri dengan lingkungan dan meningkatkan derajat kesehatan fisik dan mental anak autis. ${ }^{9}$ Menggambar dan mewarnai adalah kegiatan seni dan pengembangan potensi yang diterapkan dalam cara yang kreatif dan menyenangkan (joyful learning process). Motivasi tersebut akan mendorong anak autis melakukan kegiatan tanpa merasa tertekan atau terpaksa. Selain itu, melalui menggambar dan mewarnai, anak autis dapat mulai menghafal warna, alat-alat yang mereka gunakan dan menambah banyak kata-kata baru. Anak juga dapat mulai membaca melalui bentuk dan simbol yang merepresentasikan sesuatu. Selain itu anak dapat mengalami dan menikmati joy of create dimana mereka akan merasakan kebanggaan dan kepuasan karena dapat menghasilkan sebuah karya/artwork dan melatih sense of artistic mereka serta cara berpikir kreatif yang sangat bagus bagi perkembangan potensi anak kedepannya. ${ }^{10}$

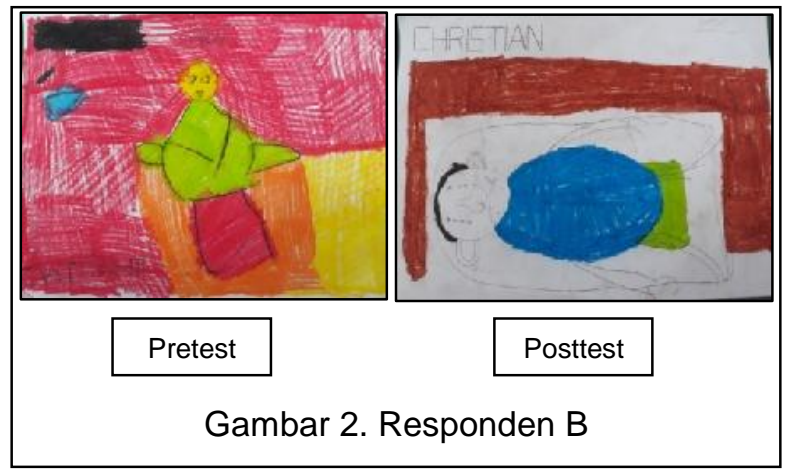

Gambar 2. menunjukkan hasil pretest dan posttest responden $\mathrm{B}$, hasil pretest menunjukkan gambar yang sulit dideskripsikan, sedangkan hasil posttest menunjukkan gambar orang sedang berlindung di bawah meja. Gambar 3. menunjukkan hasil posttest responden $\mathrm{C}$ yang menunjukkan gambar yang sama yaitu gambar orang sedang berlindung di bawah meja. Berdasarkan perbandingan hasil pretest dan posttest pada Gambar 2 dan 3 terlihat bahwa responden sudah mengerti bahwa apabila terjadi gempa bumi, tindakan yang dilakukan adalah berlindungi di bawah meja.

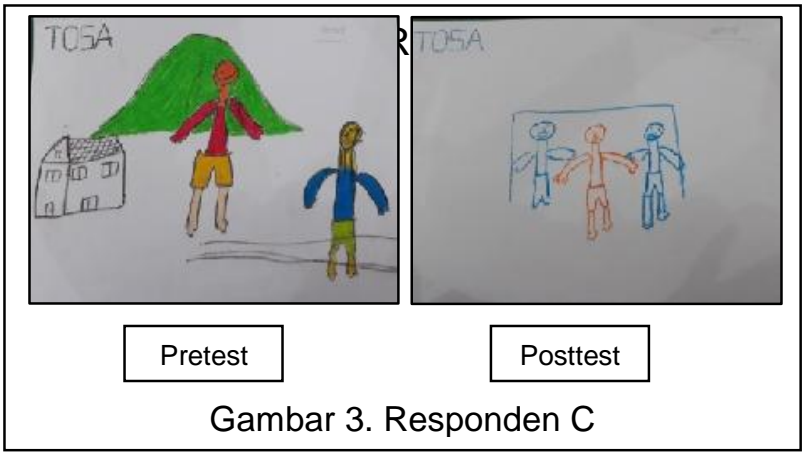

Pada penelitian ini, tidak semua respon menunjukkan adanya peningkatan pengetahuan, seperti Responden D dan E, terlihat pada gambar 4 dan 5 , yang menunjukkan tidak ada perbedaan yang signifikan antara hasil pretest dan posttest responden $\mathrm{D}$ dan responden $\mathrm{E}$.

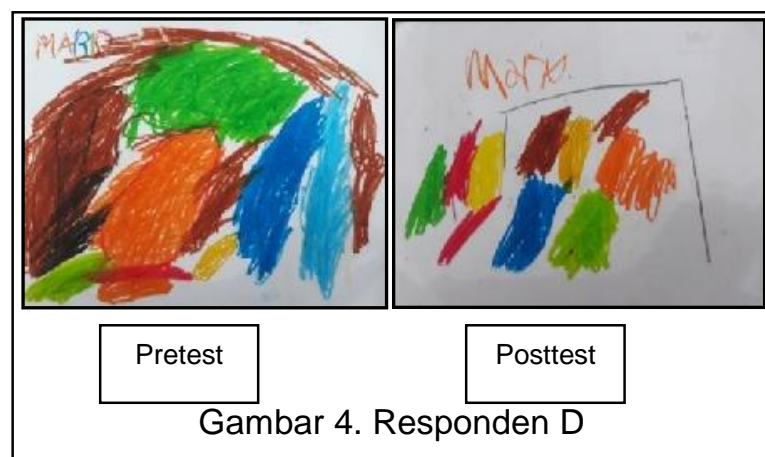

Pengaruh Pemberian Terapi Bermain terhadap Pembelajaran Mitigasi Bencana Pada Anak Autis Berbasis Disaster Nursing Competency Fika Nur Indriasari, Linda Widyarani, Prima Daniyati Kusuma

MIK P-ISSN 2252-3413, E-ISSN 2548-6266 


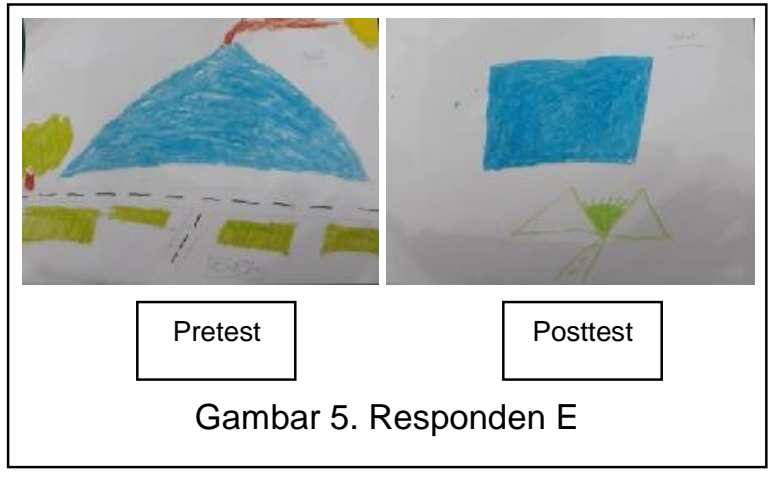

Pada penelitian ini, juga menunjukkan responden yang ternyata sudah dapat menggambarkan 1 tindakan yang dilakukan bilamana gempa bumi terjadi. Pada pretest responden $F$ dan $G$ menggambarkan orang sedang berlindung di bawah meja, sedangkan pada posttest, responden $\mathrm{F}$ dan G dapat menggambarkan orang sedang berlari keluar dari rumah, dan berlindung di bawah meja. Pada saat menggambar orang sedang berdiri di depan pintu, Responden G mengatakan "ayo lari".

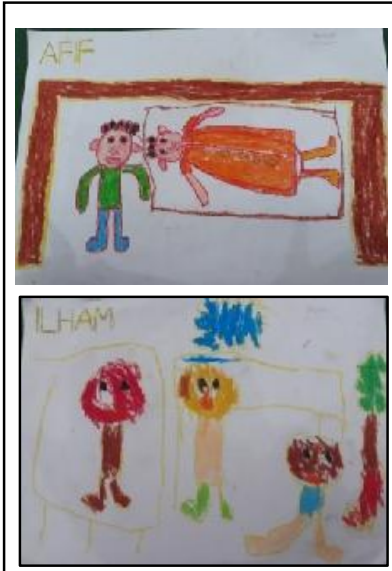

Pretest Prost
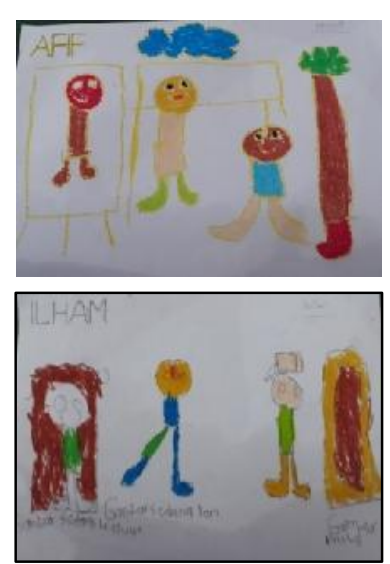

Posttest
Gambar 6. Responden F dan G

\section{KESIMPULAN}

Pada penelitian ini, metode terapi bermain menunjukkan pengaruh positif terhadap kemampuan mitigasi anak-anak berkebutuhan khusus dengan autis dalam menghadapi bencana gempa bumi di Yogyakarta. Terapi bermain dalam bentuk menggambar dan mewarnai menunjukkan pengaruh positif bagi peningkatan pengetahuan responden tentang pembelajaran mitigasi bencana gempa bumi. Keseluruhan responden, yaitu 30 orang terlibat aktif pada kegiatan pretest dan posttest. Setelah terapi bermain selesai dilakukan, 19 responden (63,33\%) mampu menggambarkan tindakan yang boleh dan tidak boleh dilakukan saat terjadi gempa bumi, terjadi peningkatan $56,33 \%$.

\section{TERIMA KASIH}

1. Direktur AKPER Notokusumo Yogyakarta, email: kangmas.giri@yahoo.com

2. Ketua PPPM AKPER Notokusumo Yogyakarta,email: tauhid_psik@yahoo.co.id

\section{KEPUSTAKAAN}

1. Widyawati dan Muttaqin. Buku Saku: Pedoman Kesiapsiagaan Menghadapi Gempa Bumi. Bandung : Divisi Manajemen Bencana Paramartha. 2010

2. Dwisiwi, R.S, Surachman, Sudomo, J \& Wiyatmo, Y. Pengembangan Teknik Mitigasi Dan Manajemen Bencana Alam Gempabumi Bagi Komunitas SMP DI Kabupaten Bantul Yogyakarta. Prosiding Seminar Nasional Penelitian. Pendidikan dan Penerapan MIPA. Fakultas MIPA. Universitas Negeri Yogyakarta Gempa Bumi. Proyek Inisiatif Keselamatan 
Sekolah Terhadap Gempa Bumi (SESI). UNCRD. 2012

3. Rinaldi. Kesiapan Menghadapi Bencana Pada Masyarakat Indonesia. Universitas Negeri Padang. Jurnal Penelitian Psikologi 14(1). 2009

4. Sutton. J \& Tierney. K. Disaster Preparedness: Concepts. Guidance. and Research. Institute of Behavioral Science University of Colorado. 2006

5. Pribadi, K.S. Penyusunan Masterplan (Rencana Induk) Penanggulangan Bencana Di Propinsi Jawa Barat. Makalah. Bandung: Pusat Mitigasi Bencana ITB 11 Agustus 2008. 2008

6. UNCRD. Mengurangi Kerentanan Anakanak Sekolah terhadap Bahaya Gempa Bumi. Proyek Inisiatif Keselamatan Sekolah Terhadap Gempa Bumi (SESI). UNCRD. 2009

7. Maulana, Mirza. Anak Autis: Mendidik Anak Autis dan Gangguan Mental Lain. Yogyakarta: Ar-Ruzz Media Group. 2007

8. Gamsiz, E.D. Intellectual Disability is associated with Increased Runs of Homozygosity in Simplex Autism. The American Journal of Human Genetics (93). 2013

9. Renzo, MD., Marini, C., Castelbianco, B., Racinaro, L., Rea, M. Correlations between the Drawing Process in Autistic Children and Developmental Indexes. Journal Psychol Psychother. (7). 2. 2017

10. Giampaolo, A,C. Drawing autism: the parental perceptions of the impact art therapy has on communication patterns and the paret-child relationship. Smith College School for Social Work Northampton, Massachusetts. 2013. 